\title{
PENGELOLAAN PROGRAM UNGGULAN PENDIDIKAN AGAMA ISLAM DI SEKOLAH MENENGAH KEJURUAN BERBASIS PESANTREN
}

\author{
Akhmad Masduqi \\ Universitas Islam Negeri Sunan Ampel Surabaya, Jawa Timur, Indonesia \\ Email: akhmadmasduqi23@gmail.com
}

\begin{abstract}
Abstrak
Penelitian ini bertujuan untuk memahami dan menganalisis tentang pengelolaan program unggulan Pendidikan Agama Islam yang ada di SMK Nurul Hidayah Al-Falah Mojokerto dalam memfasilitasi siswa untuk berkontribusi di masyarakat. Penelitian ini menggunakan pendekatan kualitatif jenis studi kasus, di mana pengumpulan datanya dilakukan melalui interview, observasi dan dokumentasi. Sedangkan analisis datanya dilakukan melalui penyajian data, reduksi data dan penarikan kesimpulan. Hasil penelitian menunjukkan bahwa pengelolaan program unggulan pada pembelajaran Pendidikan Agama Islam di SMK Nurul Hidayah Al-Falah Mojokerto dalam memfasilitasi siswa untuk berkontribusi di masyarakatnya, dilakukan secara terencana dan sistematis melalui penguatan pada program ekstrakulikuler Pendidikan Agama Islam sebagai program unggulan di lembaganya. Semua kegiatan tersebut dilakukan melalui perencanaan yang matang, dan dilaksanakan dengan mengacu pada perencanaan yang ada dan dievaluasi dengan prinsip perbaikan berkelanjutan.
\end{abstract}

Kata kunci: Pengelolaan, Program Unggulan, Pendidikan Agama Islam

\begin{abstract}
This research aims to understand and analyze the management of the flagship program of Islamic Religious Education at SMK Nurul Hidayah Al-Falah Mojokerto in facilitating students to contribute to society. This research uses a qualitative approach to the type of case study, where data collection is done through interviews, observation, and documentation. While the data analysis is done through display data, data reduction, and conclusion. The results showed that the management of the Islamic Religious Education's flagship program at SMK Nurul Hidayah Al-Falah Mojokerto in facilitating students to contribute to society was carried out in a planned and systematic manner through strengthening the Islamic Education extracurricular program as a superior program in the institution, which has types of activities. All of these activities are carried out through careful planning and are carried out concerning existing plans and evaluated with the principle of continuous improvement.
\end{abstract}

Keywords: Management, Featured Programs, Islamic Religious Education 


\section{A. PENDAHULUAN}

Pendidikan merupakan salah satu ikhtiar untuk meningkatkan dan menciptakan manusia yang berkualitas, serta bangsa yang bermartabat dan dijunjung tinggi oleh bangsa lain (Mirsal, 2017). Tolak ukur bangsa berkualitas dapat dilihat dari sejauh mana keberhasilan pendidikan dilaksanakan (Muliana, Maallah, \& Lismawati, 2020). Pendidikan merupakan salah satu unsur penilaian dalam indeks pembangunan manusia (human development index) yang dikembangkan oleh United Nations Development Programs (UNDP) (Suwardi, 2016; Panyajamorn, et al., 2018).

Pemerintah menyadari pentingnya pendidikan yang bermutu bagi bangsa Indonesia (Suhermanto \& Anshari, 2018; Dakir \& Fauzi, 2020). Pemerintah terus berupaya untuk meningkatkan mutu pendidikan nasional (Kamayuda \& Krismanda, 2016). Pendidikan dianggap cukup strategis untuk dijadikan agenda pembangunan bangsa (Alawiyah, 2017; Rosad, 2019). Seluruh potensi pendidikan hendaknya diarahkan pada pencapaian tingkat kemajuan pembangunan pendidikan yang berkualitas, baik secara kuantitatif maupun kualitatif melalui serangkaian program unggulan ekstrakulikuler yang harus dilaksanakan secara rutin.

Lembaga pendidikan Islam sebagai penyedia layanan (service provider) yang banyak diminati, sebaiknya mempertimbangkan apa yang menjadi kebutuhan stake holder terkait pendidikan (Sholihat, 2017). Hal ini sangat penting karena apabila sebuah lembaga pendidikan mengabaikannya, maka akan terjadi kesenjangan antara program yang dicanangkan sekolah dengan harapan stake holder (Sairi \& Safrizal, 2018). Terlebih lagi, ketika lembaga pendidikan Islam dihadapkan pada tantangan modernisasi yang berdampak pada merosotnya karakter dan moral peserta didik (Dakir, 2019). Dunia global sangat memerlukan pengembangan IMTAQ amat penting (Malla, 2017), karena tanpa dibingkai oleh iman dan taqwa, maka kompetensi ilmu pengetahuan dan teknologi akan menjadi kurang bermakna bagi kehidupan bangsa, bahkan dikhawatirkan akan liar dan tidak terkendali, yang mewujud dalam terjadinya erosi nilai-nilai moral (Ahmad, 2021).

Krisis moral yang menerpa bangsa ini yang ditunjukakn dengan adanya kekerasan di masyarakat, meningkatnya angka pelecehan seksual terhadap remaja dan anak-anak (Ekawati, 2018; Juwita, 2018), banyak terjadinya pergaulan bebas pada remaja kita, pencurian, pornografi, kebiasaan mengkonsumsi obat-obatan terlarang dan narkoba (Rosdiana, 2017), selalu menyontek, serta melakukan perusakan terhadap milik orang lain, merupakan permasalahan sosial yang sampai saat ini belum dapat diatasi secara tuntas (Baharun \& Mahmudah, 2018) (Wuryandani \& Senen, 2018). Hal ini disesebabkan karena pendidikan agama yang berjalan saat ini banyak bersikap menyendiri, kurang berinteraksi dengan pendidikan lainnya, sehingga perlu mendapatkan sentuhan yang professional dalam pengelolaannya (Salahudin \& Alkrienciehie, 2013; Fajriana \& Aliyah, 2019). Pendidikan agama diharapkan berjalan dan bekerja sama dengan program pendidikan umum lainnya agar, supaya kelemahan dan kekurangannya dapat teratasi, dan sesuai dengan relevansi terhadap perubahan sosial yang terjadi di masyarakat (Munif, 2016; Zulfaizah, 2018).

Untuk melakukan tindakan preventif dan kuratif untuk meminimalisir masalah seperti tersebut di atas, maka diperlukan adanya formulasi tentang sistem pendidikan yang komprehensif, integratif, seimbang, dan terpadu, atas dasar prinsip kesatuan ilmu pengetahuan 
dan ilmu agama, antara kepentingan dunia dan akhirat, material dan spiritual, jasmaniyah dan rohaniyah.

Integraated curriculum dalam hal ini mampu memberikan solusi alternative untuk memecahkan problematika pendidikan dewasa ini (Baharun, 2017)pe. Hasil penelitian menunjukkan bahwa kurikulum terintegrasi yang mengintegasrikan antara kurikulum nasional dan pondok pesantren mampu meningkatkan mutu belajar siswa di sekolah (Indana, 2018). Menurut Zaini (2020) Manajemen kurikulum terintegrasi pada madrasah di lingkungan pesantren sangat penting untuk dilakukan oleh guru dalam membantu peserta didik mencapai tujuan pembelajaran. Selanjutnya Rahman (2014) menuturkan bahwa pelaksanaan kurikulum terintegrasi terwujud pada unit-unit pembelajaran, yang masing-masing unit didukung oleh sejumlah mata pelajaran atau bidang studi.

Sekolah Menengah Kejuruan (SMK) Nurul Hidayah Al-Falah, Mojokerto, Jawa Timur, merupakan lembaga yang berada di bawah naungan Pondok Pesantren Nurul Hidayah Al-Falah Mojokerto. Sekolah ini menerapkan kurikulum gabungan (integrated curriculum) antara program kegiatan belajar formal dan non formal, antara kurikulum nasional dan kurikulum pesantren, yang dirmu menjadi satu dan berbasis pada local wisdom.

Hal menjadi kajian dalam penelitian ini adalah kegiatan belajar non formal yang menerapkan program unggulan PAI yang merupakan aspek dari kegiatan ekstrakulikuler sekolah dalam memfasilitasi siswa untuk berkontribusi di masyarakat melalui beberapa bentuk pelatihan keagamaan, misalnya pelatihan khitobah, pembacaan kitab, bilal dan khutbah jum'at, dan pelatihan qiro'ah. Program unggulan Pendidikan Agama Islam diarahkan untuk diarahkan untuk mengembangkan iman, akhlak (Maisyanah, Syafa'ah, \& Fatmawati, 2020), hati nurani, budi pekerti serta aspek kecerdasan dan keterampilan sehingga terwujud keseimbangaan (Hidayat, 2015; Saputra, 2017). Dengan demikian, pendidikan agama akan mampu memberikan kontribusi terhadap seluruh dimensi perkembangan manusia Indonesia seutuhnya (Malla, 2017; Fauzi, 2019; Iqbal, 2019).

Membangun siswa agar dapat berkontribusi di masyarakat tidaklah mudah karena kontribusi identik pada dunia investasi dan marketing. Jika dalam dunia pendidikan kontribusi dipahami sebagai nama, istilah, simbol, tanda dari semua yang digunakan untuk mengidentifikasi sekolah atau semua program yang ada di sekolah, maka kiranya sekolah dapat menganalisis dan meningkatkan kualitas layanan mereka sesuai kontribusi yang selama ini diunggulkan. Sekolah harus meningkatkan kualitas pendidikan mereka, menghargai proses pembelajaran, menggunakan sumber daya pembelajaran secara tepat (Farida Isnaeni, 2020), membuat perencanaan kurikulum lengkap dan meningkatkan minat belajar siswa. Ketika peningkatan kualitas pembelajaran sekolah sesuai dengan harapan siswa dan orang tua, maka potensi dan daya saing siswa akan ditampilkan. Siswa yang sesuai dengan harapan sekolah akan dibina, dan ini akan meningkatkan kepuasan siswa dengan semua fasilitas yang ada di sekolah tersebut.

Berdasarkan observasi awal, banyak masyarakat yang menganggap Sekolah dalam lingkup pendidikan Islam seperti halnya di Pondok pesantren kegiatannya padat, sehingga banyak para orang tua yang bangga menyekolahkan putra putrinya di Sekolah Menengah Kejuruan. Dapat diasumsikan orang tua memilih ini karena pandangan positif atau mempunyai brand image tentang sekolah tersebut dan juga orang tua percaya bahwa secara output anaknya dapat berguna di masyarakat. 
Berdasarkan beberapa pemasalahan di atas, peneliti ingin menganalisis tentang pengelolaan program unggulan Pendidikan Agama Islam yang ada di SMK Nurul Hidayah AlFalah Mojokerto dalam memfasilitasi siswa untuk berkontribusi di masyarakat.

\section{B. METODE PENELITIAN}

Penelitian ini menggunakan pendekatan deskriptif kualitatif, di mana peneliti berusaha untuk memahami beberapa aktivitas dan fenomena terkait dengan pengelolaan program unggulan Pendidikan Agama Islam dalam memfasilitasi siswa untuk berkontribusi di masyarakat di SMK Nurul Hidayah Al-Falah Mojokerto, Jawa Timur untuk diinterpretasikan menjadi sebuah temuan. Dalam hal ini peneliti mendeskripsikan gambaran secara sistematis, factual, dan akurat mengenai fakta-fakta, sifat-sifat serta hubungan antar fenomena yang tengah diselidiki.

Peneliti melakukan interview terhadap kepala sekolah, para wakil kepala sekolah, guru dan siswa di SMK Nurul Hidayah Al-Falah Mojokerto untuk mendapatkan gambaran tentang pengelolaan program unggulan Pendidikan Agama Islam dalam memfasilitasi siswa untuk berkontribusi di masyarakat. Observasi dilakukan pada aktivitas pembelajaran yang dilakukan oleh guru dan siswa, materi yang disampaikan, metode dan media yang digunakan dalam pengelolaan program unggulan Pendidikan Agama Islam dalam memfasilitasi siswa untuk berkontribusi di masyarakat.

Teknik analis data dilakukan secara bertahap dengan mengacu kepada konsep Milles and Hubberman, yaitu peneliti melakukan data display, kemudian dilanjutkan dengan reduksi data dan diakhiri dengan penarikan kesimpulan penelitian. Pengecekan keabsahan datanya dilakukan dengan memanfaatkan berbagai sumber di luar data sebagai bahan perbandingan. Kemudian dilakukan cross check agar hasil penelitian dapat dipertanggungjawabkan. Peneliti menggunakan triangulasi, yaitu dengan triangulasi sumber data dan trianggulasi metode.

\section{HASIL DAN PEMBAHASAN}

Program unggulan merupakan suatu rangkaian langkah-langkah yang digunakan untuk meningkatkan kualitas peserta didik, supaya terbangun kepercayaan pada stake holder, orang tua, dan masyarakat secara umum terhadap lembaga SMK Nurul Hidayah Al-Falah Mojokerto. Program unggulan di SMK Nurul Hidayah Al-Falah merupakan bagian dari aspek kurikulum terpadu atau integrated curriculum yang memiliki pola lebih terbuka dan luas. Keunggulan lembaga pendidikan bisa dilihat dalam beberapa ciri, yaitu; 1) kepemimpinan dan manajemen yang kuat; 2) kualitas sumberdaya yang unggul; 3) input siswa berkualitas; 4) sarana dan prasarana yang mendukung, termasuk sistem asrama jika dimungkinkan; 5) kurikulum yang berkembang secara adaptif, termasuk ekstrakulikuler; 6) kerjasama lembaga dan dukungan masyarakat luas.

Hal ini sebagaimana disampaikan H. Mokhamad Sholeh (2020) selaku Kepala SMK Nurul Hidayah Al-Falah Mojokerto bahwa; "sekolah kami memiliki program unggulan dari aspek kurikulum terpadu berupa kegiatan ekstrakulikuler Pendidikan Agama Islam. Dalam mencapai visi, misi, dan mencapai tujuan pendidikan yang diharapkan. integrated curriculum yang kami desain berusaha untuk menggabungkan kurikulum pendidikan nasional dengan metode salafiyah". Lebih lanjut dipertegas oleh Nurul Hasanah (2020) selaku WK Kurikulum bahwa SMK Nurul Hidayah Al-Falah Mojokerto yang berada di bawah naungan Yayasan 
Pondok Pesantren memiliki program unggulan untuk meningkatkan mutu pendidikan dan memberikan pelayanan yang lebih baik kepada masyarakat tentang kebutuhan mereka akan pendidikan.

Pernyataan infroman tersebut sesuai dengan hasil observasi dan dokumentasi peneliti selama di lapangan tentang berbagai program unggulan Pendidikan Agama Islam, sebagai berikut;

Tabel 1 : Program Unggulan Pendidikan Agama Islam di SMK Nurul Hidayah Al-Falah

\begin{tabular}{|c|c|c|}
\hline NO & PROGRAM & BENTUK KEGIATAN \\
\hline 1 & Program literasi & $\begin{array}{l}\text { Menyelenggarakan program literasi berupa pembacaan } \\
\text { ayat-ayat Al-Qur'an. }\end{array}$ \\
\hline 2 & Pendidikan Lanjutan & $\begin{array}{l}\text { Menyediakan pendidikan tinggi lanjutan bagi siswa SMK, } \\
\text { yaitu STAI Nurul Hidayah Al-Falah, guna untuk } \\
\text { memberikan kesempatan pada peserta didik yang kurang } \\
\text { mampu dalam perekonomian agar bisa tetap melanjutkan } \\
\text { pendidikan S1. }\end{array}$ \\
\hline 3 & Peminatan & $\begin{array}{l}\text { Sekolah menyediakan dan melaksanakan pembelajaran } \\
\text { peminatan, yaitu; } \\
\text { 1. Ilmu alat } \\
\text { 2. Lughowiyah } \\
\text { 3. Dialog bahasa Arab } \\
\text { 4. Dialog bahasa Inggris }\end{array}$ \\
\hline 4 & Boarding School & $\begin{array}{l}\text { Pondok Pesantren Nurul Hidayah Al-Falah, yang } \\
\text { menyediakan pesantren untuk siswa putra dan putri. }\end{array}$ \\
\hline 5 & Ekstrakulikuler & $\begin{array}{l}\text { Sebanyak } 25 \text { kegiatan yang bisa dipilih oleh siswa dalam } \\
\text { mengembangkan wawasannya, termasuk pelatihan } \\
\text { khitobah, baca kitab, khutbah dan bilal sholat Jum'at. }\end{array}$ \\
\hline 6 & Menyenggarakan Event & $\begin{array}{l}\text { Mengadakan event-event kegiatan tingkat Provinsi Jawa } \\
\text { Timur, yaitu Festival Banjari sejawa Timur, dan Bhatsul } \\
\text { Masail di Wilayah Kabupaten Mojokerto yang } \\
\text { dilaksanakan setiap } 1 \text { bulan sekali. }\end{array}$ \\
\hline 7 & Penyediaan sarana & $\begin{array}{l}\text { a. Menyediakan ruang perpustakaan untuk alat bantu } \\
\text { peserta didik dalam membaca materi keagamaan } \\
\text { b. Menyediakan } 2 \text { (dua) ruang Laboratorium Komputer } \\
\text { sebagai Pusat dan Sumber Belajar }\end{array}$ \\
\hline
\end{tabular}

Tabel 1 tersebut menunjukkan bahwa variant kegiatan yang dilakukan oleh SMK Nurul Hidayah Al-Falah berusaha untuk mengembangkan kompetensi dan life skill peserta didiknya agar sesuai dengan harapan masyarakat dan ready for use ketika dibutuhkan oleh masyarakatnya. Hal ini juga menunjukkan bahwa desain kurikulum yang dilakukan benar-benar berbasis pada kearifan local yang ada.

Hal yang paling menonjol dalam kegiatan program unggulan Pendidikan Agama Islam di SMK Nurul Hidayah Al-Falah Mojokerto dalam memfasilitasi siswa untuk berkontribusi di 
masyarakat adalah kegiatan ekstrakulikuler PAI. Ekstrakulikuler merupakan kegiatan di luar mata pelajaran sebagai bagian integral dari kurikulum sekolah. Kegiatan ekstra kulikuler merupakan upaya pembentukan watak dan kepribadian siswa yang dilakukan melalui pelatihan khitobah, pelatihan baca kitab, pelatihan bilal, dan pelatihan khutbah Jum'at, yang ditujukan untuk pengembangan kreativitas dan karir peserta didik, menekankan peningkatan kecakapan hidup sesuai dengan kebutuhan khusus siswa.

Ada tiga tahapan yang dilakukan dalam kegiatan tersebut, yaitu;

1. Perencanaan

Pada tahap perencanaan setiap unsur aspek kurikulum terpadu, SMK Nurul Hidayah AlFalah Mojokerto memfasilitasi siswa melalui kegiatan ekstrakulikuler PAI pelatihan khitobah, pelatihan baca kitab, pelatihan bilal, dan pelatihan khutbah Jum'at untuk berkontribusi di masyarakat. Ektrakulikuler PAI merupakan kegiatan seperti yang telah disampaikan oleh Mokhamad Sholeh (2020) selaku kepala sekolah SMK Nurul Hidayah Al-Falah Mojokerto: "untuk perencanaan program unggulan dalam aspek kurikulum terpadu, guru merencanakan proses pelaksanaan pelatihan khitobah, pelatihan baca kitab, pelatihan bilal, dan pelatihan khutbah Jum'at agar pelaksanaan dalam pelatihan terstruktur sehingga berjalan secara efektif dan kondusif sesuai harapan kami”.

Nurul Hasanah (2020) selaku Waka Kurikulum SMK Nurul Hidayah Al-Falah juga mengatakan: "rencana perangkat pembelajaran dalam bentuk berkas rencana program kerja diaplikasikan pada saat guru melaksanakan setiap aspek kurikulum terpadu pada masing-masing muatan lokal yang diampunya, khususnya guru pembimbing program unggulan ekstrakulikuler PAI".

Kedua pernyataan diatas juga dikuatkan oleh Imam Rohani (2020) selaku pembimbing ekstrakulikuler PAI di SMK Nurul Hidayah Al-Falah Mojokerto, bahwa: "dari program kerja yang kami buat secara terstruktur, tujuan dalam pelatihan khitobah, baca kitab, bilal dan khutbah Jum'at, akan berjalan secara efektif dan kondusif. Setelah program kerja sudah dalam bentuk berkas hardcopy, disetorkan kepada kepala sekolah untuk dianalisa serta disepakati. Program kerja nantinya sebagai acuan ketika kepala sekolah mengevaluasi pelatihan khitobah, baca kitab, bilal dan khutbah Jum'at".

Program kerja merupakan susunan rencana kegiatan kerja yang sudah dirancang dan disepakati bersama untuk dilaksanakan dalam jangka waktu tertentu. Program kerja harus dibuat secara terarah, sebab akan menjadi pegangan, dan pedoman sekolah dalam mencapai tujuan pendidikan. Selain itu program kerja juga dapat menjadi sebuah tolak ukur dalam pencapaian target saat guru pembimbing akan melakukan pelatihan khitobah, baca kitab, bilal dan khutbah Jum'at, hasilnya akan dievaluasi ketika masa akhir semester.

Tujuan dari perencanaan program unggulan SMK Nurul Hidayah Al-Falah Mojokerto, untuk lancar dan kondusifnya pelaksanaan serta proses pelatihan khitobah, pelatihan baca kitab, pelatihan bilal, dan pelatihan khutbah Jum'at. Perencanaan tersebut ditujukan untuk menciptakan program unggulan sebagai penunjang dalam pembelajaran Pendidikan Agama Islam di Sekolah, sehingga tujuan pembelajarannya dapat tercapai dan mampu menghasilkan out put peserta didik sesuai yang diharapkan

Umat Islam pada umumnya merindukan sebuah lembaga pendidikan Islam yang unggul dan berprestasi (Awwaliyah, 2018). Tujuan munculnya sekolah dengan potret pesantren/Islami 
merupakan proses santrinisasi masyarakat muslim Indonesia. Dalam hal ini diperkuat juga oleh Mokhamad Sholeh (2020) kepala SMK Nurul Hidayah Al-Falah, yaitu: "siswa pada umumnya telah mengalami Islamisasi namun perlu mendapat perhatian dan penekanan lebih mendalam lagi, selain mempelajari ilmu-ilmu umum secara berkualitas. Mereka dibimbing lebih intensif bagaimana membaca kitab kuning dan berpartisipasi di masyarakat dalam kegiatan ke agamaan hingga membentuk peserta didik untuk bersosial dengan nilai-nilai ajaran subtansial dalam Islam".

Untuk menjadikan sekolah yang berada di dalam naungan Yayasan Pondok Pesantren itu benar-benar unggul, perlu sebuah formulasi konsep, visi-misi, dan tujuan yang hendak dicapai oleh lembaga itu. Sekolah berbasis pesantren memiliki keunggulan bukan sekedar slogan atau nama, melainkan mengemban amanah yang mulia untuk melahirkan lulusan yang mutunya baik. Visi-misi dan tujuan itu kemudian dijadikan sebagai acuan serta nilai-nilai bagi para pemimpin, guru dan karyawan dan peserta didik untuk mendasari setiap aktivitas dan kegiatan pembelajarannya.

Seperti yang telah disampaikan oleh Nurul Hasanah (2020); "melalui hasil program unggulan PAI dengan aspek kurikulum terpadu berupa ekstrakulikuler pendidikan agama Islam yang terdapat komponen kegiatan ke agamaan yaitu, pelatihan khitobah, baca kitab, khutbah dan bilal sholat Jum'at, ketika para siswa belajar di SMK Nurul Hidayah Al-Falah itu pulang ke rumah, mereka dapat berkontribusi di masyarakat sekitarnya dengan baik sesuai dengan tujuan dari visi-misi lembaga juga merupakan kebutuhan siswa kami juga ketika sudah selesai menempuh pendidikannya“".

Pada perencanaan kegiatan ekstrakulikuler khitobah, bilal dan khutbah sholat Jum'at telah dijelaskan oleh Imam Rohani (2020) guru pembimbing ekstrakulikuler PAI di SMK Nurul Hidayah Al-Falah Mojokerto; "Pada perencanaan ekstrakulikuler khitobah, bilal dan khutbah sholat Jum'at, kami menyusun acara mulai dari protokol/pembagi waktu sampai acara penutup yaitu pembacaan doa, ada petugas utama ada tugas kedua sebagai cadangan dari petugas utama apabila ada halangan sakit/izin pada petugas utama, jadi kegiatan tidak akan terganggu”.

Perencanaan pelatihan baca kitab (nahwu-shorof) di SMK Nurul Hidayah Al-Falah Mojokerto merupakan ekstrakulikuler PAI yang berjalan setiap hari setelah Isya', kecuali hari Kamis dan Jum'at. Pelatihan baca kitab ini dilakukan mulai pukul 20.00-22.00 WIB. Didalam perencanaannya mengacu pada kalender pendidikan Nasional, seperti halnya pembelajaran muatan lokal Bahasa Daerah.

SMK Nurul Hidayah Al-Falah Mojokerto memiliki 25 kegiatan ekstrakulikuler yang terprogram ini, ada 4 ekstrakulikuler pendidikan agama Islam yang bersifat wajib bagi peserta didik, karna ini merupakan kegiatan yang dapat membangun keualitas peserta didik dalam daya pikir, daya fisik, serta daya qalbu, juga dapat menunjang pengoptimalan kualitas terhadap peserta didik ketika output dari SMK Nurul Hidayah Al-Falah untuk berkontribusi di masyarakat.

\section{Pelaksanaan}

Pelaksanaan ekstrakulikuler PAI merupakan program unggulan PAI yang memberikan fasilitas kepada siswa di SMK Nurul Hidayah Al-Falah Mojokerto untuk dapat berkontrubusi di masyarakat pasca mereka menamatkan pendidikannya di sekolah. Kegiatan ekstrakulikuler Pendidikan Agama Islam dimulai dengan mendata kehadiran siswa mulai dari kelas X, XI, dan 
XII. Untuk mengetahui kehadiran siswa, dilakukan kegian absendi dua kali, (1) acara sebelum dimulai, (2) acara sebelum ditutup oleh pembimbing dari ekstrakulikuler pendidikan agama Islam tersebut.

Dalam hal ini, ekstrakulikuler pendidikan agama Islam yang memiliki beberapa aspek kegiatan sekaligus dalam pelaksanaannya, yaitu;

a. Pelatihan khitobah

Pada pelatihan khitobah terdapat komponen macam-macam kegiatan religi misalnya, protokol/pembawa acara dalam kegiatan keagamaan maupun umum di masyarakat nanti, serah-terima acara pernikahan, pembacaan kitab untuk pengajian umum, pembacaan do'a untuk acara di masyarakat umum. Kegiatan ini memberikan pelatihan dan pembinaan kepada siswa tentang bagaimana mereka mampu menjadi bagian dalam berbagai kegiatan yang ada di masyarakatnya.

Seperti yang telah dijelaskan oleh Nurul Hasanah (2020) Waka Kurikulum SMK Nurul Hidayah Al-Falah Mojokerto, bahwa: "pelaksanaan pelatihan khitobah ini terstruktur secara bergantian dari minggu ke minggu mendatang, maksudnya setiap poin dalam kegiatan khitobah, peserta didik mendapat tugas untuk menampilkan secara langsung, sesuai poin urutan yang ada didalam acara khitobah tersebut”.

Pandangan tesebut diperkuat oleh guru pembimbing ekstrakulikuler khitobah di SMK Nurul Hidayah Al-Falah Mojokerto, sebagai berikut: "dalam pelaksanaan khitobah, tiap-tiap siswa dan tiap-tiap poin yang ada didalam khitobah, dilaksanakan secara berurutan sesuai urutan poin yang ada dan dilakukan oleh berbeda-beda siswa, misalnya, siswa yang bernama Muhajir mendapat bagian protokol (pembagi waktu dalam kegiatan), maka dy akan membuka acara khitobah diawal kegiatan ekstrakulikuler khitobah dilaksanakan, diteruskan dengan siswa yang berbeda misalnya, pembacaan ayat suci AlQur'an yang dibacakan oleh siswa atas nama Ibrahim, dan seterusnya sampai do'a penutup acara khitobah dibacakan, dengan sesuai pembagian nama siswa dan poin dalam kegiatan khitobah tersebut da nada cadangan bagi petugas pelaksanaan poin kegiatan khitobah agar saat petugas utama tidak ada karna sakit/ijin, pelaksanaan kegiatan tetap berjalan sesuai perencanaan, dan manfaat dari peserta didik yang akan tampil kedepannya mengetahui secara langsung bagaimana tata cara pelaksaan suatu kegiatan pelatihan tersebut".

Peserta didik mendapat tugas secara bergilir dengan dipilih secara langsung oleh Pembimbing ekstrakulikuler PAI SMK Nurul Hidayah Al-Falah Mojokerto. Pada petugas pertama yang dipilih oleh pembimbing, dapat menggunakan buku panduan/materi yang telah diberikan dari sekolah dan sekaligus guru pembimbing memberikan bimbingan secara langsung kepada peserta didik. Dari permasalahan sebelumnya, peserta didik yang mendapat tugas selanjutnya memperoleh dan mengorganisasikan informasi secara faktual.

Petugas cadangan merupakan pengganti dari petugas utama, apabila petugas utama tidak dapat mengikuti pelatihan karena sakit ataupun ada keperluan lain kecuali Alfa. Tugas cadangan dibentuk memiliki tujuan untuk tetap kondusifnya kegiatan pelatihan khitobah. Dengan adanya tugas cadangan tersebut, kegiatan pembinaan kesiswaan dapat berjalan dengan efektif dan efisien. 
b. Pelatihan bilal dan khutbah untuk sholat Jum'at

Pada tahap kegiatan pelatihan bilal dan khutbah Jum'at di SMK Nurul Hidayah Al-Falah Mojokerto dilaksanakan sama persis seperti pelaksanaan pada saat siswa melakukan kontribusi bilal dan khutbah Jum'at di masyarakat pada umumnya, terutama di Dusun Bedagas Desa Tunggalpager Kecamatan Pungging Kabupaten Mojokerto, akan tetapi dalam pelaksanaan pelatihan terdapat pembuka acara dengan pembagi waktu agar acara pelatihan dapat terlaksana secara terstruktur.

Kegiatan pelatihan bilal dan khutbah Jum'at, dibuka dan ditutup dengan mengucapkan salam oleh pembimbing pelatihan bilal dan khutbah Jum'at. Kemudian pembimbing mendata absensi kehadiran siswa, pada pendataan absensi kehadiran siswa dilakukan dua kali di akhir pelatihan, untuk menjaga agar kegiatan tetap kondusif dan melatih siswa dalam kedisiplinan. Kegiatan pelatihan tersebut ditujukan agar siswa mampu melakukan tugas keagamaan dalam aktivitas di masyarakat, sehingga mereka dapat redy for use.

Strategi pembelajaran dalam pelatihan bilal dan khutbah Jum'at dilakukan dengan cara yang sama pada pelatihan khitobah, adanya petugas utama juga petugas cadangan, untuk mengantisipasi apabila petugas utama tidak bisa hadir karna sakit maupun ijin lainlain. Melalui petugas cadangan tersebut, kegiatan dapat berjalan dengan baik tanpa harus menunggu kehadiran dari petugas yang sesungguhnya

c. Pelatihan baca kitab

Pada tahap pelaksanaan pelatihan baca kitab di SMK Nurul Hidayah Al-Falah, guru pembimbing ekstrakulikuler melaksanakan sesuai RPP yang telah dibuat sebelum proses pembelajaran/pelatihan dilaksanakan. RPP merupakan pedoman bagi guru untuk menentukan arah dan tujuan pembelajaran yang akan dilaksanakan dalam kegiatan pembelajarannya. RPP berisi tentang tujuan yang akan dicapai yang jabarkan melalui Standar Kompetenso, Kompetensi Dasar, Materi yang akan disampaikan, pendekatan atau metode yang akan digunakan, pemanfaatan media dan sumber belajar serta evaluasi yang akan digunakan untuk mengukur keberhasilan dari kegiatan yang dilakukan.

Adapun tahap awal dimulai dari (1) salam sebagai pembuka proses pelatihan baca kitab, (2) memberikan mukadimah berupa pembacaan surah Al-Fatihah yang ditujukan kepada Nabi Muhammad SAW, (3) menentukan tema bab pada materi yang akan dijelaskan kepada peserta didik, (4) mulai menjelaskan materi baca kitab, (5) melaksanakan tanya jawab kepada peserta didik, (6) memberikan kesempatan pada peserta didik dengan memberikan contoh yang berbeda dari guru pembimbing, (7) penutup membaca surah Al-Fatihah diteruskan salam penutup dan diakhiri dengan bacaan sholawat kepada Nabi Muhammad SAW.

Dalam observasi pelatihan ini penulis mendapat dukungan berupa pernyataan dari guru pembimbing ekstrakulikuler PAI (baca kitab), yaitu: "dalam pelaksanaan proses belajar mengajar pelatihan baca kitab ini kami membuat rencana proses pembelajaran agar kegiatan berjalan dengan terstruktur, mulai dari acara (1) salam pembuka, dilanjutkan dengan acara ke 2, (2) mukadimah membaca surah Al-Fatihah yang dikirim kepada Nabi Muhammad SAW dengan tujuan ilmu yang kita pelajari nanti mendapat 
manfaat dan barokah dari-Nya, (3) kami tentukan tema bab sesuai perkembangan peserta didik dalam memahami materi yang telah disampaikan, misalnya pada kitab Nahwu AlJurumiyah di bagian Bab I membahas tentang "كلمة", (4) selanjutnya kami jelaskan secara detail mengenai materi didalam bab "كلمة" tersebut, (5) Tanya jawab dengan peserta didik mengenai bab "كلمة", (6) peserta didik memberikan contoh yang berbeda dengan contoh yang kami berikan, (7) kegiatan penutup dengan membaca surah Al-Fatihah lagi diteruskan salam penutup sekaligus bacaan sholawat kepada Nabi Muhammad SAW".

Proses pelaksanaan pembelajaran pelatihan baca kitab dilakukan secara terstruktur semi KBM formal di SMK Nurul Hidayah Al-Falah Mojokerto, dengan demikian selesai kegiatan proses pelatihan baca kitab dapat tepat waktu sesuai dengan penentuan kerangka waktu yang telah ditentukan. Hal ini menunjukkan bahwa kegiatan pembinaan program unggulan yang dilakukan oleh sekolah telah berjalan dengan baik, sehingga mampu menciptakan program unggulan Pendidikan Agama Islam efektif dan efisien.

3. Evaluasi

Evaluasi merupakan kegiatan akhir dari pelaksanaan pelatihan khitobah, baca kitab, bilal, dan khutbah Jum'at. Guru pembimbing mengevaluasi peserta didik dengan mengukur dan menilai hasil penampilan dari peserta didik yang mendapat tugas pada saat itu. Kegiatan evaluasi yang dilakukan tersebut ditujukan untuk mengetahi kelebihan dan kekurangan dari program yang sudah berjalan guna ditindak lanjuti dengan perbaikan dan penambahan atau pengurangan program selanjutnya.

Guru pembimbing dan peserta didik yang menyaksikan penampilan dari temannya, menganalisa penampilan dari tiap-tiap petugas (peserta didik), kemudian menunjukkan kekurangan dan kelebihan dari yang telah ditampilkan oleh peserta didik, kemudian memberikan nilai sesuai penampilan peserta didik juga dengan kesepakatan bersama antara guru pembimbing dan peserta didik yang menyaksikan penampilan temannya didepan dengan memperhatikan standar kompetensi dan kompetensi dasar.

Tabel 2. Standar Kompetensi Dan Kompetensi Dasar Khitobah

\begin{tabular}{|l|l|}
\hline \multicolumn{1}{|c|}{ STANDAR KOMPETENSI } & \multicolumn{1}{c|}{ KOMPETENSI DASAR } \\
\hline 1) Tajwid & 1. Makharijul huruf \\
& 2. Sifat Al huruf \\
& 3. Ahkan Al huruf \\
& 4. Ahkam Almad wal qasor \\
\hline 2) Fashohah & 1. Ahkan Al waqof wal ibtida' \\
& 2. Mura'at Al huruf Wal harokat \\
& 3. Muro'at Al kalimat Wal ayat \\
\hline 3) Suara & 1. Kejernihan / kebeningan \\
& 2. Kehalusan \\
& 3. Kenyaringan \\
& 4. Keutuhan \\
& 5. Pengaturan nafas \\
\hline
\end{tabular}




\begin{tabular}{|l|l|}
\hline \multicolumn{1}{|c|}{ STANDAR KOMPETENSI } & \multicolumn{1}{c|}{ KOMPETENSI DASAR } \\
\hline 4) Mental & 1. Siap (penyampaian disampaikan dengan lancar) \\
& 2. Kurang persiapan (gugup) \\
& 3. Tidak siap (banyak kalimat yang salah/lupa) \\
\hline 5) Lagu dan bacaan & 1. Lagu penyampaian \\
& 2. Perhatian, keutuhan, dan tempo penyampaian \\
& 3. Irama dan gaya \\
& 4. Variasi \\
\hline
\end{tabular}

Misalnya pada pelatihan khitobah, yang memiliki tujuan mengembangkan bakat, minat dan prestasi siswa untuk bersosial, meningkatkan kemampuan dan keterampilan siswa dalam bersosial, mempersiapkan siswa untuk berkontribusi di masyarakat, dan Sasaran dari kegiatan ini adalah siswa kelas XI dan XII.

Observasi penulis dalam evaluasi pelatihan khitobah dan bilal-khutbah Jum'at ini dikuatkan oleh pernyataan dari guru pembimbing ekstrakulikuler PAI, yaitu: "strategi dalam mengevaluasi kegiatan pembelajaran/pelatihan khitobah dan bilal-khutbah Jum'at kami lakukan dengan mengajak peserta didik selain peserta didik yang mendapat tugas untuk menganalisa kekurangan serta kelebihan yang ada pada petugas/peserta didik dalam menampilkan rincian yang ada pada pelatihan khitobah dan bilal-khutbah Jum'at. Dengan tujuan, agar peserta didik dapat mengevaluasi dirinya menjadi lebih baik dari penampilan temannya yang mendapatkan tugas pada saat itu".

Evaluasi dari pelatihan baca kitab dilakukan setelah guru menjelaskan materi, yaitu dimulai dari tahap tanya jawab dengan peserta didik kemudian peserta didik diberi kesempatan untuk memberikan contoh dengan contoh yang berbeda dari guru pembimbing berikan. Adapun tujuan dari evaluasi pada pelatihan baca kitab ini, sepertinya yang telah dikemukakan oleh Imam Rohani (2020) guru pembimbing PAI, yaitu: “evaluasi dalam pelatihan baca kitab ini bertujuan untuk, (1) sesi tanya jawab untuk mengukur sampai sejauh mana pemahaman peserta didik dalam memahami materi yang telah kami sampaikan, (2) peserta didik kami beri kesempatan untuk memberikan contoh dengan contoh yang berbeda dari yang sudah saya berikan, agar peserta didik nantinya benar-benar memahami materi yang saya sampaikan ketika sudah dipraktikkan sendiri”.

Evaluasi yang dilakukan pada pelatihan baca kitab di SMK Nurul Hidayah Al-Falah memiliki perbedaan dan juga persamaan. Perbedaan terdapat pada penerapan guru pembimbing menggunakan metode pendekatan konstruktif dan persamaan dari evaluasi tersebut, guru pembimbing mengevaluasi peserta didik dengan menggunakan metode pendekatan konstruktif.

Dari pernyataan hasil wawancara diatas dapat penulis simpulkan. Perencanaan untuk berkontribusi di masyarakat, SMK Nurul Hidayah Al-Falah Mojokerto memfasilitasi siswa dengan program unggulan dari aspek implementasi kurikulum terpadu berupa model program ekstrakulikuler/pengembangan diri.

Berangkat dari temuan penelitian tersebut di atas, dapat dipahami bahwa program unggulan melalui aspek dari kurikulum terpadu atau integrated curriculum yang memiliki pola terbuka dan luas juga sejalan dengan pendapat Ma'arif (2013) yang menyatakan bahwa 
kurikulum terpadu (integrated curriculum) yaitu kurikulum yang meniadakan batas-batas antara berbagai bidang dan didalam mata pelajaran tersebut terdapat keterpaduan mata pelajaran.

Kurikulum terintegrasi (integrated curriculum) lebih memandang bahwa dalam suatu pokok bahasan harus integrated atau terpadu secara menyeluruh (Sunardi \& Fajri, 2019). Keterpaduan ini dapat dicapai melalui pemusatan pelajaran pada satu masalah tertentu dengan alternatif pemecahan melalui berbagai disiplin ilmu atau mata pelajaran yang diperlukan sehingga batas-batas antara mata pelajaran dapat ditiadakan (Rahman, 2014).

Kebebasan pada pola kurikulum terpadu merupakan kegiatan ekstrakulikuler PAI sebagai kegiatan pendidikann diluar mata pelajaran yang ada didalam bagian integral dari kurikulum SMK Nurul Hidayah Al-Falah Mojokerto. Dalam kegiatan esktrakulikuler PAI sebagai bentuk upaya pembentukan watak dan kepribadian peserta didik yang dilakukan melalaui kegiatan pelatihan berkenaan dengan masalah pribadi dan kehidupan sosial, kegiatan belajar, dan pengembangan siswa (Fachri, Wahid, \& Lailiyah, 2020). Khususnya pelatihan ditujukan guna pengembangan kreativitas dan karir untuk satuan pendidikan khusus, pelatihan khitobah, baca kitab, bilal, dan khutbah Jum'at menekankan peningkatan kecakapan hidup sesuai dengan kebutuhan khusus siswa ketika selesai dalam pendidikan di SMK Nurul Hidayah Al-Falah Mojokerto.

\section{KESIMPULAN}

Program unggulan Pendidikan Agama Islam merupakan aspek dari kurikulum terpadu yang memiliki pola terbuka luas atau meniadakan batasan-batasan antara berbagai bidang dan di dalam mata pelajaran tersebut terdapat keterpaduan mata pelajaran. Ekstrakulikuler Pendidikan Agama Islam sebagai program unggulan di SMK Nurul Hidayah Al-Falah Mojokerto memiliki empat jenis kegiatan, (1) pelatihan khitobah (2) pelatihan baca kitab (3) pelatihan bilal sholat Jum'at (4)pelatihan khutbah sholat Jum'at. Kegiatan tersebut dalam pelaksanaannya berjalan sesuai dengan yang direncakan, karena ditangani secara khusus oleh beberapa pengurus yang bertanggung jawab pada bidangnya masing-masing.

Penelitian ini memberikan implikasi pada terhadap pentingnya desain kurikulum untuk menciptakan pendidikan dan pembelajaran yang bermutu dalam mempersiapkan mental dan spiritual peserta didik agar supaya ready for use di masyarakatnya, dan didasarkan pada kebutuhan masyarakat. Hasil penelitian ini tidak dapat digeneralisir untuk dipraktikkan pada semua jenajng dan lembaga pendidikan, akan tetapi ini hanya terbatas pada SMK Nurul Hidayah yang memiliki karakteristik, kearifan lokal, setting budaya dan letak geografis tertentu. Keterbatasan penelitian ini, memberikan peluang dan kesempatan kepada para peneliti selanjutnya untuk mengkaji tema yang sama dalam karakteristik dan setting yang berbeda.

\section{DAFTAR PUSTAKA}

Ahmad. (2021). Konsep Kurikulum Terintegrasi: Analisis Kurikulum Formal dengan Pesantren. Ilmuna, 3(1), 66-84.

Alawiyah, F. (2017). National Standards of Primary and Secondary Education. Aspirasi, 8(1), 81-92.

Awwaliyah, R. (2018). Pendidikan Islam Dalam Sistem Pendidikan Nasional (Telaah Epistemologi Terhadap Problematika Pendidikan Islam). Jurnal Ilmiah DIDAKTIKA, 19(1), 
34-49. https://doi.org/10.1017/CBO9781107415324.004

Baharun, H. (2017). Pengembangan Kurikulum: Teori dan Praktik (Konsep, Prinsip, Model, Pendekatan dan Langkah-langkah Pengembangan Kurikulum PAI). Yogyakarta: Cantrik Pustaka.

Baharun, H., \& Mahmudah. (2018). Konstruksi Pendidikan Karakter Di Madrasah Berbasis Pesantren. Jurnal Mudarrisuna, 8(1), 153.

Dakir. (2019). Manajemen Pendidikan Karakter: Konsep dan Implementasinya di Sekolah dan Madrasah. Yogyakarta: K-Media.

Dakir, \& Fauzi, A. (2020). Manajemen Mutu Pendidikan Islam Terpadu; Strategi Pengelolaan Mutu Madrasah dan Sekolah di Era Revolusi Industri 4.0. Yogyakarta: Pustaka Pelajar.

Ekawati, M. S. dan K. S. (2018). Moderasi Kurikulum Perguruan Tinggi Islam dalam Deradikalisasi Agama di Indonesia. Istiqro', 16(1), 139-178. Retrieved from http://istiqro.kemenag.go.id/index.php/istiqro/article/view/97/82

Fachri, M., Wahid, A. H., \& Lailiyah, K. (2020). Joyful Learning Berbasis Hypercontent Dalam Meningkatkan Motivasi Belajar Siswa Pada Pembelajaran Pendidikan Agama Islam (PAI) di Sekolah. Edureligia: Jurnal Pendidikan Agama Islam, 4(2), 170-184.

Fajriana, A. W., \& Aliyah, M. A. (2019). Tantangan Guru dalam Meningkatan Mutu Pendidikan Agama Islam Di Era Melenial. Nazhruna: Jurnal Pendidikan Islam, 2(2), 246-265. https://doi.org/10.31538/nzh.v2i2.324

Fauzi, A. (2019). Epistemologi Pendidikan Islam Rahmatan Lil 'Alamin di Era Revolusi Industri 4.0; Sebuah Kajian Paradigmatik. Edureligia: Jurnal Pendidikan Agama Islam, 3(2), 92100. Retrieved from http://jurnaljpi.com/index.php/JPI/article/view/28

Hidayat, N. (2015). Peran Dan Tantangan Pendidikan Agama Islam Di Era Global. Jurnal Pendidikan Agama Islam, 12(1), 61-74. https://doi.org/10.14421/jpai.2015.121-05

Indana, N. (2018). Penerapan Kurikulum Terintegrasi Dalam Mengembangkan Mutu Belajar Siswa (Studi Kasus di SMA Darul 'Ulum 1 Unggulan BPPTJombang). Nidhomul Haq: Jurnal Manajemen Pendidikan Islam, 3(2), 121-147. https://doi.org/10.31538/ndh.v3i2.80

Iqbal, M. (2019). Pengaruh antara Pendidikan Agama Islam di Sekolah dengan Pendidikan Agama dalam Keluarga. At-Ta'dib: Jurnal Ilmiah Prodi Pendidikan Agama Islam, 11(1), $61-80$.

Juwita, Y. F. dan. (2018). Utilization of Video Blogs (Vlogs) in Character Learning in Early Childhood. Jurnal Obsesi: Jurnal Pendidikan Anak Usia Dini, 2(2), 211-218. https://doi.org/10.31004/obsesi.v2i2.87

Kamayuda, D. M. D., \& Krismanda, M. A. (2016). Perencanaan Strategi Bersaing Sekolah Dalam Meningkatkan Mutu Pendidikan Di Sekolah Swasta Salatiga. Satya Widya, 32(2), 79-91.

Maisyanah, Syafa'ah, N., \& Fatmawati, S. (2020). Strategi Guru Pendidikan Agama Islam dalam Membentuk Akhlakul Karimah Peserta Didik. At-Ta'dib: Jurnal Ilmiah Prodi Pendidikan Agama Islam, 12(1), 15-30.

Malla, H. A. B. (2017). Pembelajaran Pendidikan Agama Islam Berbasis Multikultural Humanistik dalam Membentuk Budaya Toleransi Peserta Didik Di SMA Negeri Model Madani Palu, Sulawesi Tengah. INFERENSI: Jurnal Penelitian Sosial Keagamaan, 11(1), 163-186. https://doi.org/10.18326/infs13.v11i1.163-186 
Mirsal, I. (2017). Konsep Pendidikan Multikultural dalam Perspektif Islam. At-Ta'dib: Jurnal Ilmiah Prodi Pendidikan Agama Islam, 9(1), 69-89.

Muliana, Maallah, M. N., \& Lismawati. (2020). Efektivitas Manajemen Kelas Terhadap Pelajaran Pendidikan Agama Islam. Al-Ibrah, 9(2), 146-163.

Munif, M. (2016). Pengembangan Pendidikan Agama Islam Sebagai Budaya Sekolah. Jurnal Pedagogik, 3(2), 46-57.

Panyajamorn, T., Suanmali, S., Kohda, Y., Chongphaisal, P., \& Supnithi, T. (2018). Effectiveness of E-learning Design and Affecting variables in Thai Public Schools. Malaysian Journal of Learning and Instruction, 15(1), 1-34.

Rahman, K. (2014). Pengembangan Kurikulum Terintegrasi DI Sekolah/Madrasah. J-PAI: Jurnal Pendidikan Agama Islam, 1(1), 13-48. https://doi.org/10.18860/jpai.v1i1.3358

Rosad, A. M. (2019). Implementasi Pendidikan Karakter melalui Managemen Sekolah. Tarbawi: Jurnal Keilmuan Manajemen Pendidikan, 5(2), 173-190. https://doi.org/10.32678/tarbawi.v5i02.2074

Rosdiana. (2017). Prinsip Dasar Pendidikan Anak Menurut Perspektif Al-Qur'an. Idaarah: Jurnal Manajemen Pendidikan, 1(1), 105-120. https://doi.org/10.24252/idaarah.v1i1.4131

Sairi, A., \& Safrizal, M. (2018). Pengaruh Mutu Layanan Sarana dan Prasarana Terhadap Kepuasan Siswa. JMKSP (Jurnal Manajemen, Kepemimpinan, Dan Supervisi Pendidikan), 3(1), 20-27. https://doi.org/10.31851/jmksp.v3i1.1520

Salahudin, A., \& Alkrienciehie, I. (2013). Pendidikan Karakter (Pendidikan Berbasis Agama Dan Budaya Bangsa). Bandung: Pustaka Setia.

Saputra, A. (2017). Pelaksanaan Pendidikan Agama Non Formal dalam Pembinaan Masyarakat Islami. At-Ta'dib: Jurnal Ilmiah Prodi Pendidikan Agama Islam, 9(1), 91-104.

Sholihat, S. S. (2017). Pengelolaan Biaya Pendidikan, Partisipasi Masyarakat, Dan Mutu Layanan Pembelajaran Madrasah Ibtidaiyah Swasta. Jurnal Administrasi Pendidikan, 24(1), 1-10. https://doi.org/10.17509/jap.v24i1.6497

Suhermanto, S., \& Anshari, A. (2018). Implementasi TQM terhadap Mutu Institusi dalam Lembaga Pendidikan. Al-Tanzim: Jurnal Manajemen Pendidikan Islam, 2(1), 107-113. https://doi.org/10.33650/al-tanzim.v2i1.259

Sunardi, \& Fajri, W. (2019). Aktualisasi Kurikulum Terintegrasi di SMA Trensains Tebuireng Jombang. TA"LIM : Jurnal Studi Pendidikan Islam, 2(1), 45-68.

Suwardi. (2016). Commitment of Teachers and Professionalism. Proceeding 2nd International Conference on Education and Training 2016, 211-215.

Wuryandani, W., \& Senen, A. (2018). Implementasi Pemenuhan Hak Anak melalui Sekolah Ramah Anak. Jurnal Civics : Media Kajian Kewarganegaraan, 15(1), 86-94.

Zaini, M. (2020). Penguatan Manajemen Kurikulum Terintegrasi pada Madrasah di Lingkungan Pesantren. Falasifa, 11(1), 79-103.

Zulfaizah. (2018). Revitalisasi Pendidikan Agama dalam Pembentukan Karakter Peserta Didik di Madrasah. ELEMENTARY, 6(1), 43-62. 